\title{
Geleneğin Savunusu: Türkiye'de Geleneksel Şark Medreseleri ve Müderrislerinin (Seydaların) Modern Din Eğitimine Eleştirileri
}

\section{The Defense of Tradition: The traditional Orient madrasas and the critiques of its muderrises (seydas') to Modern Religious Education in Turkey}

Deniz Aşkın a,*

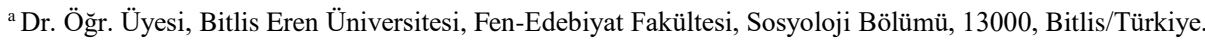
ORCID: 0000-0003-0827-0534

\section{MAKALE BİLGISI}

Makale Geçmişi:

Başvuru tarihi: 01 Şubat 2019

Düzeltme tarihi: 17 Temmuz 2019

Kabul tarihi: 23 Ağustos 2019

\section{Anahtar Kelimeler:}

Şark Medreseleri

Medrese Eğitimi

Din Eğitimi

Seyda

\section{A R T I CLE INFO}

\section{Article history:}

Received 01 Febryary 2019

Received in revised form 17 July 2019

Accepted 23 August 2019

\section{Keywords:}

Oriental Madrasas

Education of madrasa

Religious Education

Seyda
ÖZ

Osmanlı Devleti'nin yıkılmasından sonra kurulan Türkiye Cumhuriyeti'nin toplumsal yapısının birçok alanında olduğu gibi eğitim politikasında da radikal değişiklikler meydana geldi. Ancak bu süreçte toplumsal dönüşüme katılmayan dini eğitim merkezlerinden bir kısım medreseler, bazı bölgelerde müderrisler ve halk tarafından günümüze kadar devam ettirilmişlerdir. $\mathrm{Bu}$ süreçte medreselerin müderrisleri ve bu kurumların baş aktörü olan seydalar günümüz modern din eğitimine bazı eleştiriler getirerek bir anlamıyla kendileri ve kurumları için güven tazelemeye çalışmaktadırlar. Bu eleştiriler, çoğunlukla sınırlı din eğitimi, eğitim-öğretim yöntemi, öğrenciöğretmen ilişkisi, din eğitiminin yeterli olmaması ve geleneksel eğitime ait bir takım özellikler etrafinda şekillenmektedir. Nitel verilere dayanan bu çalışma süresince Türkiye'nin farklı illerine dağılan seydalara ve medreselere kartopu örneklem metodu ile ulaşılarak toplamda 30 seyda ile derinlemesine görüşmeler yapılmıștır.

\section{A B S T R ACT}

Fundamental changes took place in the education policy and other fields of the social structure in the Turkish Republic which was founded after the collapse of Ottoman Empire with a secular state structure. However, madrasas as a center of religious education didn't participate in the social transformation totally especially in the eastern and southeastern of Turkey in the process. Although madrasas were illegal they have been continued by mudarris and local people in the regions of Turkey. Seydas as muddaris and the leading actor of madrasas criticize the modern Turkish religious education system in order to restore trust both for themselves and for their institutions. The critiques are centered on the religious education limited by the state, teaching method, studentteacher relationship, not being enough, and a set of features related to traditional madrasa education. The method of this study is qualitative. Due to the fact that seydas and madrasas were scattered across different cities and snowball sample technique was used to reach 30 seydas with whom in-depth interviews were conducted.

\section{Giriş}

İnsanın var oluşundan beri devam eden eğitim, süreç içerisinde sosyal ve kültürel hayatın argümanları ile kurumsallaşırken, çoğunlukla gelecek kuşağın nasıl olması gerektiği üzerine odaklanır. Ancak gerek insanoğlunun her zaman ve her mekânda karşılaştığ 1 sorunların farklı olması gerekse de bilginin ve deneyimin birikerek ileriye doğru yeni kapılar açması hem eğitimin yenilenmesini hem de bireyin sosyalleşmesini ya da sosyalleştirilmesini gerekli kılmaktadır. $\mathrm{Bu}$ yönden bakıldığında toplumsal dönüşümler, eğitimde olması gereken reformların habercisi olarak önceki kriterlerin bugünkü problemlere yetersiz kaldığına işaret etmektedir (Durkheim, 1977: 92). İslam toplumlarında İslamiyet'in doğuşundan itibaren devam eden, dini eğitimin temel amacı birey iyi bir Müslüman

\footnotetext{
* Sorumlu yazar/Corresponding author.

e-posta: denizaskin13@gmail.com
} 
olarak yetiştirmek ve temel dini değerleri ileriye taşımaktır. İlk zamanlar ibadet mekânları etrafında gelișen ve küçük ders halkaları ile başlayan eğitim, İslam dininin eğitime verdiği büyük öneme bağlı olarak kısa sürede gelişme imkânı bulmuştur. Bu süreçte Müslümanlar arasında okuma yazma bilenler az olduğundan Yahudi öğretmenlerden destek alınmış ve ilk etapta 17 kişi olan okuryazar sayısı kısa zamanda 42'ye yükseltilmiştir. Bunun sonucu olarak da eğitim, daha geniş alanlara yayılma imkânı bulmuştur. Mescitlerin inşa edilme sürecine değin, evlerde devam eden eğitim sistemi, Medine'de açılan mescit ile İslam tarihinde ilk eğitim kurumu olan Suffa inşa edilmiş oldu (Gül, 1997:1-2). Ancak bu sistem günümüz anlamıla kurumsallaşmış değildir. $\mathrm{Bu}$ nedenle Osmanlı eğitim sistemi, her ne kadar İslamiyet'in bu ilk eğitim kurumların kültürel mirasından faydalanmışsa da, kurumsal anlamda 11. yüzyılda büyük Selçuklular döneminde Vezir Nizâmülmülk öncülüğünde kurulan Nizamiye medreselerine dayanır.

Selçuklular döneminde kurulan ve İslam'ın kurumsal eğitim merkezi özelliğini kazanan Nizamiye Medreseleri'nin kurulma gerekçesinde, klasik anlamda eğitim ve öğretime verilen önem ile birlikte o dönemde Büveyhoğulları (Irak, Suriye ve Mısır) ve Fatımilerin yaymaya çalıştıkları Şiilik mezhebinin de etkisi oldukça büyüktür. Bunun yanında mescitlerin artan nüfusun eğitim ihtiyacına cevap verememesi, ibadet mekânlarının kalabalık olması da yine Selçuklularda kurumsal bir eğitim sistemine geçilmesini bir nevi zorunlu hale getirmiştir. Ayrıca Fatımiler'in Selçuklu topraklarını ele geçirme gayeleri yine halkın Sünnililk mezhebi doğrultusunda iyi bir şekilde eğitilmesini gerekli kılıyordu. Bu amaçla Selçuklular bu tür sosyal ve siyasal tehlikelere karşı önlem almak için "gayesi ve hedefi yüksek ĕgitim kurumları kurdular, Şiiliğe karşı savaştılar ve Fatımi propagandasını tesirsiz hale getirmek için tedbir almakta gecikmediler" (Talas, 2000: 29). Bu tür nedenler etrafında şekillenen yeni eğitim kurumu, hem devletten hem de zengin kişilerden destek almasından ötürü kısa zamanda önemli ilerlemeler kaydetmiştir. Anadolu Selçukluları döneminde Anadolu topraklarına da taşınan eğitimin bu kurumsal mirası Osmanlı Devleti'nin faydalandığı önemli bir kültürel sermaye olmuştur.

İslamiyet'in yayılmaya başlaması sürecinde kurulan küçük çaplı eğitim kurumları Büyük Selçuklu Devleti döneminde Nizamiye medreselerinin de temelini oluşturmuştur. Osmanlı eğitim sistemi de bu kurumsal yapının bir devamı olarak sürmüş ve eğitimin kurumsal yapısına katkı sağlamıştır. Devlet politikaları ile paralel bir şekilde devam eden eğitime süreç içerisinde gittikçe önemli bir misyon yüklenmiştir. $\mathrm{Bu}$ anlamıyla süreç sadece eğitim boyutuyla kalmayıp bu kurumlar zihinsel dönüşümün gerçekleştirildiği mekânlar haline gelmiştir. Osmanlılar, hem Selçuklulardan hem de İslam kültüründen almış oldukları miras üzere gittikleri yerlerde yeni mescit ve medreseler inşa ederek eğitim sistemini hem sosyal hem de siyasal istikrar gözetilerek geliştirmiştir. $\mathrm{Bu}$ bağlamda Osmanlı'da kurulan ilk kurumsal medrese Orhan Gazi tarafından İznik'te kurulan İznik Orhaniye'si adlı medresedir (Maltaş, 2011: 250). Bununla beraber medreseler Osmanlı döneminde yönetici sınıfın eğitimi için önemli bir kuruma dönüşerek devletin ihtiyaç duyduğu uzman kadro, bu tür eğitim kurumlarından sağlanmıştır. Ayrıca eğitim bu kurumlarda eğitilen kişilerce sürdürüldüğünden (Türk 1999: 33) kurum içinde radikal anlamda dönüşümler meydana gelmemiştir.

Osmanlı'nın sosyal, siyasal, ekonomik, eğitim ve diğer askeri alanlarda üstün başarı elde ettiği ilerleme döneminde medreseler oldukça önemli bir konum kazanmıştır. Bunun nedeni medreselerin sadece dini eğitime değil fenni ilimlere de yoğunlaşmasıydı. Gerileme döneminde ise, azalmaya başlayan devlet gücünün bu olumsuz etkisi eğitim kurumu olan medreselere de sirayet etmiştir. Medrese eğitiminin artık sosyal ve siyasal ihtiyaçları karşıla(ya)madığı düşünülerek Tanzimat döneminde Batı tarzı eğitim veren ve Osmanlı eğitim sisteminin "medrese-mektep ikilemi" içerisine girmesine neden olan "mektep ithali" olarak tabir edilen yeni modern bir form kabul edilmiştir (SDAM, 2016: 1-3). Medreselere alternatif olarak kurulan mekteplerden mezun olanların devlet kurumlarında istihdam edilmeleri; ancak buna karşılık medrese mensuplarının bu tür görevlerin dışında bırakılması, medreselerin de süreç içerisinde halka mal olmasına neden olmuştur. Bu tarihten sonra 1923'te modern anlamda ulus devlet temelinde kurulan Türkiye Cumhuriyeti'nde 1924 yılında Tevhid-i Tedrisat Kanunu (3 Mart 1924) çıkarılarak daha önce meydana gelen eğitimdeki bölünme tekrar bir elde toplanarak modern anlamda okul çatısı altında birleştirilmiştir. Eğitim ve öğretimin birleştirilmesinden kısa bir süre sonra çıkarılan 447 sayılı yeni bir genelge ile medreselerin eğitim ve öğretim faaliyetine son verilmiş ve ülke genelinde yasaklanmıştır (Çağlayan, 2018: 52). Buna rağmen medreseler ${ }^{1}$ özellikle Doğu ve Güneydoğu Anadolu bölgelerinde günümüze kadar varlıklarını korumuşlardır. Ancak medreselerin illegal bir zeminde varlığını sürdürmesi kendi üzerinde bir özeleştiri mekanizmasını geliştirememesi için önemli bir neden olarak karşımıza çıkmaktadır. Bu kurumu devam ettirenlerde yakalanma ve medreselerinin kapatılma korkusu eğitim kurumlarının müfredatlarına dışardan gelebilecek herhangi bir eleştirinin önünü kapatmasının yanında, kurum müdavimlerinin bu geleneğin kurumsal faaliyetlerini devam ettirme konusuna yoğunlaşmaları onların bu şekilde dar bir alana kapanmasına neden olmuştur (Doğan, 2013, 11). Medresenin müderrisi ve kültürel bir aktör olarak ön plana çıkan ve Kürtler arasında $s e y d a^{2}$ olarak tabir edilen kişiler günümüz Şark medreselerinin öncü aktörleri olarak öne çıkmaktadır. Bu yönüyle son zamanlarda seydaların siyasal anlamda bir meşruiyet arayışına girmesi (Aşkın, 2018) klasik anlamdaki medrese eğitimi üzerindeki tartışmaları yeniden canlandırmıştır. Bu çalışmanın temel problemi de, Osmanlı Devleti'ndeki medrese geleneğine dayanan günümüz Şark medreseleri müderrislerinin yani seydaların hangi konularda modern din eğitimini eleştirerek kendileri için meşruiyet zemini inşa etmeye çalıştıklarına odaklanmaktadır.

\footnotetext{
1 Günümüz medreselerinin çoğunlukla Doğu ve Güneydoğu Anadolu bölgelerinde bulunmalarından dolayı, anlam karışıklığını önlemek için, bu çalışmada klasik Osmanlı eğitimi sisteminin devamı olan bu medreseler "Şark medreseleri" olarak tanımlanmıştır.

${ }^{2} \mathrm{Bu}$ çalışmada görüşme yapılan bütün seydaların kişisel bilgileri kendi istekleri üzerine değiştirilmiştir.
} 


\section{Türkiye Cumhuriyeti'nde Din Eğitimi}

Türkiye'deki din eğitimi üzerine geniş bir literatür olmakla beraber bu konunun tam olarak net bir görüntü kazandığ 1 söylenemez. Daha önceleri sadece kendi Müslümanları değil ama bununla beraber tüm İslam âleminin (ümmet) siyasi liderliğini bünyesine katmış olduğu halifelik ile sürdüren bir devletin seküler bir devlete evirilmesi muhakkaktır ki kısa zamanda yerleşmeyecek bir takım radikal değişiklikleri meydana getirmiştir. $\mathrm{Bu}$ nedenle, kurulan laik devlet kendi argümanlarını oluştururken ortaya koyduğu siyasal uygulamalar eğitim sistemini de şekillendirmiştir. Cumhuriyet döneminin önemli siyasetçilerinden olan Falih Rıfkı'nın (1933:16) kendilerinden önceki Osmanlı yöneticilerini eleştirerek onların yapamadıkları 'millet inşa'sını kendilerinin oluşturacağını ifade etmesi doğal olarak ulus devlet modelini ortaya koymayı gerektirmiştir.

Türkiye'nin modern laik, ulus devlet modelinde inşa edilme sürecinde geleneksel olarak kabul edilen tekke ve zaviyelerin kapatılmasını, Türkiye'nin aydınlanma çağının belirtileri olarak değerlendiren Bodur (2007: 35) bu inşa sürecinde eğitimde birliği sağladığını ifade etmektedir. Bayar'a göre (2012: 21) Cumhuriyet döneminden bugüne kadar Türkiye'de eğitim genel olarak elit bir sınıfın elinde bulunmuştur. Eğitim ile devlet içindeki farklı gruplar bir araya getirilerek eğitilir ve onlarda 'teklik' ve 'birlik' bilinci oluşturulur. Vahide'ye (2006: 57-58) göre Mustafa Kemal'in açık hedefi Batı medeniyetini Osmanlı'dan kalan küller üzerine inşa etmektir. Böyle bir niyet öncelikle kurumsal anlamda eski yapıların yenilenmesi ile mümkün olduğu göz önünde bulundurulursa askeri, yasal ve siyasal alanda atılan adımlar anlam kazanır. $\mathrm{Bu}$ yönüyle kurucu parti olarak Cumhuriyet Halk Partisi'nin (CHP) parti programında yer alacak olan altı ilke doğrultusunda özellikle eğitim alanı "ulusal, evrensel, seküler, pozitivist" değerler ile yeniden inşa edilmiştir. Daha sonraki politikalar ile bireylerin sisteme entegre edilmesini sağlamak için (Russel, 2001: 24) eğitim zorunlu hale getirilmiştir.

Cumhuriyet'in kurulması ile beraber din ve dini değerler, toplum için birleştirici bir olgu olarak kabul edilmiştir. Daha açık bir ifade ile İtalya, Fransa ve diğer Avrupa ülkelerindeki gibi din ulusal bir ruha büründürülmüş ve ulusal değerler ön plana çıkarılmıştır. Dolayısıyla, uhrevi hayata atıfta bulunan, insanları manevi kardeşlik ruhu ile besleyen dini duygular, devlet ve ulusal aidiyetin kutsallaştırılması ile bayrak, marş ve mitler üzerine inşa edilen yeni bir yoruma kavuşturulmuştur. Dini eğitimin içeriği bu doğrultuda güncellenmiş, buna yönelik olarak da İslamiyet öncesi ahlaki değerler ön plana çıkarılmış ve yeni din yorumuyla birleştirilmiştir (Bayar, 2012: 32). Bu yönüyle Türkiye'de ulusalcılık inşasında eğitimin önemi azımsanmayacak ölçüde değerlidir. Ulusal eğitim yoluyla düzene tehlike unsuru olabilecek grupların tek bir kimlik etrafında buluşturulması hedeflenmiştir (Yavuz, 1999:205).

Ulus devletin din ile olan bu kisa ilişkisinden sonra Türkiye'de din adamlarının nasıl yetiştirilmesi gerektiği de önemli bir konu olarak yeni laik cumhuriyetin önünde durmaktayd. Tevhid-i Tedrisat Kanunu'ndan sonra Türkiye'nin toplamda 29 yerleşim yerinde temel düzeyde dini bilgisi olacak kişileri yetiştirmek amacı ile imam hatip okulları açılmıştır.
Daha sonra yeni açılanlar da dâhil olmak üzere bu kurumlar öğrenci yokluğu gerekçesiyle tamamen kapatılmışlardır. Ancak bu okulların kapatılması toplumsal olarak bir takım sorunları doğurmuştur. Bunların başında Türkiye toplumunun gündelik hayatında İslam dinindeki ritüelleri icra ederken yaşadığı sıkıntılar gelir. Ölü yıkama, gömme, Cuma namazlarında hutbeyi okutacak veya namaz kıldıracak kişilerin yeterince bulunamaması gündelik hayatta bazı tepkileri doğurmuş ve siyasilerin bu konuda çalışmalar üretmesine neden olmuştur. Sonuç olarak 1948 yılında imam ve hatip yetiştirmek üzere kurslar açıldı (Şimşek 2013: 24). Aradan geçen bu süreçten sonra imam ve hatip kurslarının yetersizliği ve halkın memnuniyetsizliği ile beraber 1951 yılında 7 ilde tekrardan imam hatip okulları eğitim vermeye başladı. Bu okullar da 1973 yılında Milli Eğitim'in Temel Kanunu'na girerek 'İmam Hatip Lisesi' olarak yeni bir statü kazandı. Ancak temel amacı din adamı yetiştirmek olan bu liseler dahi Türkiye'nin siyasi serüvenin de bir takım programlar etrafında şekillenmiştir (Akşit ve Coşkun 2004). Buna rağmen bu tarihten sonra gerek okul gerekse de öğrenci sayısında önemli bir artış yaşanmış ve günümüzde de yaşanmaya devam etmektedir. Ancak bu tarihler arasında sadece Türkiye'de post-modern darbenin yaşandığı 28 Şubat (1997) sürecinde imam hatip liselerindeki öğrenci sayısı önemli oranda azalmıştır. Milli Eğitim Bakanlığı 2017 yılı verileri itibari (MEB, 2017, 122) ile 138802 açık lisede ve 506516 örgün lisede olmak üzere toplamda 645318 lise düzeyinde din eğitimi alan öğrenci bulunmaktadir.

Aynı süreçte 1924 yılında kapatılan medreselerin yani din eğitimi veren kurumların yerine, o zamanlarda ülkenin tek üniversitesi olan İstanbul Üniversitesi 'ne (Darül Fünun) bağlı olarak lisans düzeyinde İslam dini eğitimi veren bir ilahiyat fakültesi de açıldı. Bu tarihten 1933 yılına kadar faaliyet gösteren ilahiyat fakültesi bundan sonra bir takım gerekçeler ile kapatılmış ve yerine 'İslam Tetkikleri Enstitüsü' açılmıştır. Ancak bu da 1936'da gerek bazı hocaların emekliye ayrılması gerekse de başka görevlere kaymaları sonucu kapatıldı. Bunu izleyen süreçte 1949 yılında Ankara Üniversitesi'ne bağlı olarak yeni bir ilahiyat fakültesi açıldı. Kapatılan bu dini eğitim merkezlerinin tekrardan açılmasının da Türkiye özelinde bazı nedenleri mevcuttur. Bunlar arasında Türkiye'nin 1946 yılı itibari ile çok partili sisteme geçmesi ve Rusya'da başlayan komünizm propagandasının etkisi oldukça önemlidir. Bununla beraber çok partili sistem içerisinde seçimlere giren Demokrat Parti'nin (DP) kendi propagandasında öne çıkarmış olduğu dini ve kültürel değerler onun yönetime dâhil olmasını sağlamıştır. $\mathrm{Bu}$ sosyo-politik etkilerden sonra Türkiye'nin farklı yerlerinde dini eğitim merkezleri sınırlı da olsa açılmış ve gerekli bütçe için görüşmeler yapılmıştır (Şimşek 2013: 23). Bunları da ülkenin bazı yerlerinde ilahiyat fakülteleri ve İslam enstitülerinin açılması takip etti (Öcal, 2008: 403). 2017-2018 y1lı itibari ile Yüksek Öğretim Kurumu verilerine göre ${ }^{3}$ dini anlamda yüksek eğitim veren 62 İlahiyat Fakültesi- ilahiyat ön lisans, 23 İslami İlimler Fakültesi ve 1 Uluslararası İslam ve Din Bilimleri Fakültesi olmak üzere toplamda 95 birim ve bunlarda eğitim gören toplamda 120152 öğrenci bulunmaktadır.

\footnotetext{
${ }^{3}$ https://istatistik.yok.gov.tr/ (Erişim tarihi: 27.08.2018)
} 


\section{Yöntem}

$\mathrm{Bu}$ çalışmanın saha uygulaması 2017 yılının Mart ayında Türkiye'nin farklı illerinde bulunan medreselerle iletişime geçilerek kurumun öncü aktörü olan seydalar ile yapılan mülakatlara dayanmaktadır. Öncelikle ifade etmek gerekir ki, medreselerin ve medrese eğitiminin yasal zeminden mahrum olmasından dolayı bu kurumlar çoğunlukla birbirlerinden bağımsız bir şekilde devam etmektedir. Her bir seyda medresesini sahiplenmekte ve bu durum onun medresesinde eğitim gören tüm öğrenciler tarafindan da koşulsuz olarak kabul edilmektedir. Aynı şekilde her bir seyda kendi medresesine istediği sayıda öğrenci almak ve eğitmek hakkına sahiptir. Bunun yanında özellikle büyük ve köklü medreselerin zamanla daha da genişlemesi ile Türkiye'nin çeşitli yerlerine gönderilen talebeler seydalarına bağlı olarak yeni medreseler açmışlardır. Bu nedenle örneklemler Türkiye'nin farklı bölgelerinde görüşmeyi kabul eden seydalar ile gerçekleştirilmiştir. Çalışma nitel bir araştırma olması hasebiyle yorumlayıcı metodolojinin temel referanslarına dayanmaktadır. Bunun yanında bu süreçte kullanılan teknikler ve verilerin elde edilmesi aynı şekilde yorumlayıcı metodolojinin sunduğu imkânlarından faydalanılmıştır. Bu çalışmada böyle bir metodolojinin kullanılmasının temel iki nedeni mevcuttur. Birincisi örneklem grubunun gayri resmi olması hasebiyle onların kültürel ve kurumsal yapıları hakkında kamuoyunca yeterli bilginin olmaması; ikincisi ise yorumlayıcı metodun araştırmacıyla sunmuş olduğu bir rehberlik ile çalışma konusuna ait parça ve bütün ilişkisini kurmasına (Neuman, 2012: 130-131) imkân vermesidir. Çünkü bu metot ile araştırmacı olarak sahada yapılan gözlem ve görüşme sonrasında elde edilen veriler birleştirilerek görünenin derin bilgisine ulaşılmaya çalışılmıştır. Bununla beraber nitel çalışmaların bir özelliği olarak doğal ortama olan sadakat (Büyüköztürk vd, 2012: 235) bu çalışmanın gözlem, görüşme ve yorum bilgisi ile çalışma alanına odaklanılmasına imkân tanımıştır. Örneklem grubunun geleneksel eğitimlerinin sürdüğü medreselere gidilerek görüşmeler gerçekleştirilmiştir. Bu tekniğin kullanılmasının temel nedeni ise örneklem grubunun yönettiği medreseleri yakından görüp onun ve öğrencileri arasındaki ilişkiyi gözlemlemektir. Bununla beraber kartopu örneklem bulma yöntemi ile görüşülen bu kişilerin her birinin farklı yerlerde bulunması onların ancak ziyaret edilerek diğer kişilere ulaşmayı mümkün kılmasıydı. Görüşülen bu 30 kişilik örneklem grubunun sözlü anlatım yoluyla aktarmış olduğu verilerin daha sonra analizleri yapılmıştır. $\mathrm{Bu}$ yönüyle çalışmanın örneklemleri ile görüşmeler Muş, Bitlis, Van, Diyarbakır, Siirt, Batman, Bingöl, Şanlıurfa, Mardin, Konya, Ankara ve İstanbul illerinde gerçekleştirilmiştir. Bu bağlamda yarı yapılandırılmış görüşme formu kullanılarak toplamda 30 seyda ile derinlemesine görüşmeler yapılmıştır. Onların kendi meşruiyetlerini sağlamak amacıyla geliştirdikleri stratejiler ve hangi yönlerden modern din eğitimini ve eğiticilerini eleştirdiklerini anlamak maksadıyla sorular sorulmuştur.

\section{Veriler ve Analiz}

$\mathrm{Bu}$ çalışmanın temel analiz nesnesi seydalar ile yapılan görüşme kayıtlarıdır. Ancak saha çalışması sırasında yapılan gözlemlerden de faydalanılarak konunun bütünlüğü sağlanmaya çalışılmıştır. Çalışmanın aktörü medresenin müderrisi konumundaki seydadır. Verilerin iyi bir şekilde anlaşılması için de 'seyda'nın kim olduğuna kısaca bakmak yerinde olacaktır. Etimolojik kökeni Arapça'ya dayanan 'seyda' Kürt toplumunda geleneksel olarak din ve dünyevi ilişkileri tayin eden kültürel bir içeriğe sahip olmakla beraber Arapça'daki efendi anlamına gelen seyitten türemişstir (Aşkın, 2018: 6). Ancak Yalar'a (2012: 459) göre ise seyda Kürtler arasında Farsça'daki efendim, büyüğüm anlamina gelen seyyida'dan gelerek zamanla seydaya inkılap etmiştir. Bu yönüyle seyda günümüzde medrese sahibi olmayı ve onun bünyesinde ders vermeyi gerekli kılan ancak buna karşılık toplum içinde önemli bir prestije karşılık gelen kültürel/geleneksel bir statüdür. Çalışma süresince kullanılacak 'imam' ise resmi devlet okullarında eğitim görmüş din adamlarını tanımlamaktadır.

Seydalığın cumhuriyet döneminde medreselerin yasaklanması ile beraber halk arasında özellikle dini yönüyle öne çıktığını söylemek mümkündür. Bir anlamıyla Weber'in geleneksel eylem tiplemesinin (Weber 2012: 132) temel özelliklerini içinde barındıran örneklem grubu seydaların, bulundukları toplum içinde geleneksel anlamda kazanmış oldukları meşruiyetlerinin de devamı için onların resmi din eğitimine getirdikleri eleştirileri sıklaştırdıkları görülmektedir. Buradaki meşruiyet kaynakları seydaların resmi ve modern anlamda yetişmiş kişileri eleştiriye tabi tutmalarına sevk ettiğini görmek de mümkündür. Ancak verilere bakıldığında eleştirilerin tek bir noktada gerçekleşmediği anlaşılmaktadır. $\mathrm{Bu}$ eleştirilerde gizli olarak ulus devlet ve onun din eğitimi üzerine kurmuş olduğu denetim göze çarpmaktadır. Bununla beraber modern eğitim kurumlarında yetişen din adamlarının temel anlamda dini bilgilere sahip olup, ancak bilgi anlamında derine inemediği yönündeki eleştiriler de aslında geleneksel toplumdaki eğitime yönelik özellikleri ortaya koymaktadır.

Gerçekten de seyda sosyolojik olarak Arapça'daki karşılığına uygun bir şekilde anlam kazanmıştır. Günümüzde her ne kadar seydalar arasındaki iletişim zayıflasa da onların kendi özellerinde geleneksel/kültürel statülerini korumak için bir takım stratejiler geliştirdikleri muhakkaktır (Aşkın, 2019: 198). Saha çalışması sırasında öncelikle geleneksel medrese eğitimini devam ettiren bu seydalara, seydanın kim olduğu ve toplumsal olarak karşılığının ne olduğu sorularak onların bir din adamından beklentileri anlaşılmaya çalışılmıştır. Bu soruya karşılık;

Seyda kelimesi efendi demektir, müşerref demektir, hoca demektir, büyük demektir, halkın dilinde ise üstat demektir. Yani ders veren yönlendiren kişi demektir. Mesela Arapça'da üstat kelimesi biraz akademik bir kelimedir. Ancak seyda ise insanları eğiten, insanlara hocalık edebilen kişidir. Seyda ayrica medreselerde ders verebilen kişidir. Seydalar sadece baş müderris değildir. Seyda kelimesi sadece ilme has bir kelime ya da sadece imama bă̆lı bir kelime de değildir. Bu ikisini bir araya getiren kişidir (Musa, 58 Yaşııda).

Seyda Musa, halk tarafindan şehir merkezinde olmasına rağmen çok iyi tanınmaktadır. Muhtemelen bu arka plandan dolayıdır ki, Seyda Musa halkın seydaya atfettiği anlamı bu şekilde geniş almaktadır. Ancak burada önemli olan seydanın normal bir imam veyahut medresede ders veren bir müderrisin çok daha ötesinde kendisini konumlandırmasıdır. Bunu ortaya çıkaran bir takım sosyal şartlardan da bahsetmek mümkündür. Örneğin özellikle Türkiye'nin Doğu ve Güneydoğu Anadolu şartları 
düşünüldüğünde okuma, yazma ve dini bilgilerin tek elde toplanması seydanın öne çıkmasına yardımcı olduğu düşünülebilir. Diğer bir ifade ile özellikle kırsal bölgelerde seyda İslam hukukuna hâkim olmakla toplumdaki davaları çözerken aynı zamanda medresede hem imamlık yapmakta hem de ders verebilmektedir. Bu bağlamda, halk arasında gerek tarihsel ve kültürel gerekse de ilmi birikimi ile ön plana çıkan ve saygı gören seydanın resmi devlet okullarında yetişen kişilere yönelttiği eleştiriler, aslında onların sahip oldukları ve kendileri gibi bir din adamından beklentilerini kapsadığını sonraki ifadelerden anlamak mümkündür:

Medresede eğitim alan bir din görevlisi ile resmi din eğitimi alan kişiler arasındaki farka yönelik soruya karşılık Seyda Ömer:

Medrese mezunu ve medrese eğitimi almamış din adamları arasinda gördüğ̈̈m en büyük fark; benim talebem topluma gittiğinde hiç bir zaman yabancllık çekmez. Topluma kendisini kabul ettirebilir. Ama diğer taraftaki imam (resmi okulda yetişmiş) bir köye, bir yere gittiği zaman orada gün saylyor. Acaba ben ne zaman buradan gidebilirim. Toplum zaten onu kabul etmiyor. Medrese mezunu ise askere gittiğinde bile ne zaman tezkere alacă̆ım kendi yerime gideceğim diyerek tezkere günlerini sayıyor. En büyük fark budur. Yani bizimkiler halkın içerisindedir, halkla birlikte oluyor kendisini halka kabul ettirmiş, halkın dertleriyle dertleniyor (Ömer, 52 Yaşında).

Yaklaşık yüz yıl boyunca yasal zeminden yoksun olarak devam eden medreselerin en büyük kaynağı halkın kendisidir. Ancak bu konuda madalyonun diğer yüzüne bakmak ve halkı böyle bir tercihe sevk eden nedenleri görmek gerekir. Örneğin, halkın merkezi atamalar ile bölgeye gelen din adamının kendisi ile iletişime girmekte zorlanması, mezhebi olarak pratikte bir takım farklılıkların ortaya çıkması, toplumsal problemler olması durumunda din görevlisinin konuya yabancı olması gibi sıkıntılar bölge halkının kendi din görevlilerini yetiştirmeye ve bunu sağlayan seydaya ve medreseye da büyük önem vermelerini gerekli kılmıştır. Bu çalışmayı önemli kılan noktalardan biri olan seydanın toplumsal rolü günümüzde dahi bölgesel de olsa sürmekte ve seydalar bu rollerini güncel k1lmak için resmi eğitimden de destek alarak bir nevi uzmanlaşmaya doğru gitmektedirler. Benzer bir çalışmada Çiçek (2009:159) modern eğitim kurumlarında dini bilimlerde akademisyenlik yapan kişilerden ziyade medrese hocalarına -seyda- din âlimi gözüyle bakıldığını aktarmaktadır. Bununla beraber halk bu kişilere karşı iyi niyetle yaklaşırken, halk arasında medrese öğrencilerinin bulunduğu bir meclisin duasının kabul olacağına yönelik inanç hâkimdi. $\mathrm{Bu}$ durum günümüzde büyük çoğunlukla aşınmasına rağmen medresesi ve seydası olan köylerin daha fazla 'muteber' kabul edildiği açık bir şekilde görülmektedir. Alan araştırması sırasında gidilen bazı köylerde, seydası olan köylere merkezi atama ile atanan imamlar seyda tarafından daha disiplinli çalışmak durumunda bırakılırken, seydası olmayan yerlerde merkezi atamalar ile gelen imamların hem çalışma saatleri düzensiz hem de halk ile kurmuş olduğu ilişki çok daha zayıf olduğu alan gözlemleri ve halk ile yapılan görüşmelerce sabittir. Örneğin X köyüne gidildiğinde halka resmi imam ile ilgili sorular sorulduğunda çoğunlukla ona karşı hoşgörüsüz bir şekilde "bilmiyoruz ki nereye gitmiş zaten başka bir yerden gelmiș, kendisine bir de araba almış her gün ilçeye gidiyor" şeklindeki ifadeleri imamın halk ile kurmuş olduğu ilişkisinin derecesini yansıtmaktadır. Buna karşılık seydası olan bir köye atanan resmi bir köy imamı seydanın varlığından dolayı, çok fazla görünür olamamakta ve sadece seydanın kendisine belirlediği görevleri yapmanın hem avantajını hem de dezavantajını yaşamaktadır. Alan araştırması sırasında merkezi yerleştirme ile gelen bir imam ile yapılan bir sohbette seydanın kendisine onun köyde olmadığı durumlarda gerekli olan dini ritüelleri gerçekleştirmesini isterken, bunun dışında bir fonksiyonu bulunmadığını, bu nedenle halk arasında öne çı(a)madığı ve kendi statüsünü kullan(a)madığını aktarması dikkat çekicidir. Bu durum bir din adamı için bir dezavantaj olarak değerlendirilebilir. Fakat genel olarak düşünüldüğünde imam, seydanın kendisine çizdiği sınırların dışına çıkmadığı takdirde seydanın onu topluma kabul ettirme ve onun onaylanmasına katkı sağlaması bir avantaj olarak değerlendirilebilir. Nitekim alan araştırması sırasında hem seydası olan köyün bu tür avantajları ve dezavantajları ile karşılaşan hem de seydanın otoritesine karşı geldiği için bir an önce köyden ayrılmak isteyen imamlar ile karşılaşılmıştır. Burada dikkat çeken bazı noktalar mevcuttur. Bunlardan birincisi resmi devlet okullarında eğitim alan din görevlilerinin yerel dini ve toplumsal sorunlara yabanc1 kalması ve seydanın yerelden olması hasebiyle görmüş olduğu saygınlıktır. Çalışma kapsamında medresede yetişen ve o müfredata tabi olan kişilerin imam hatip ve ilahiyatçları hangi açıdan eksik gördüklerini ve onlardan ne bekledikleri yönündeki düşünceleri tespit etmenin önemli olduğu görülmüştür. Çünkü din eğitimi verilen Türkiye Cumhuriyeti eğitim sisteminde medreselerin neden halen alternatif bir eğitim kurumu olarak devam etmekte 1srar ettikleri kurum aktörlerinin dayandıkları temel nedenleri anlaşılması ile mümkün olabilir. Örneğin, medreselerde eğitim veren seydaların resmi okullardaki din eğitimine karşı bakışlarına yönelik sorulan soruya;

Bugün kesinlikle sistemin desteklediği ilahiyatçlların ve imam hatiplilerin din ĕgitiminde çok eksikleri vardır. Yani bugün oradan mezun olan kişi topluma inemiyor. Mezun olan ögrenci topluma kanaat önderi olamiyor. Topluma rehber olamıyor. Topluma öncülük edemiyor. Toplumun içine düştügü çıkmaza, derdine çare olmuyor. Yani onun için medrese hem ilahiyatçıların hem de imam hatiplilerin medreseden geçmesi lazım. (İlyas, 43 Yaşında).

Seydaların büyük ihtimalle kendi icra ettikleri fonksiyonları imam hatip ya da ilahiyat fakültelerinden mezun olan din adamlarından da bekledikleri ve buna karşılık gelen bir icraatlarını görmedikleri için onları eksik ve yetersiz gördükleri anlaşılmaktadır. Resmi okullardan mezun olup medrese eğitimi almayan kişilerin topluma inemediğini, kendilerinin yaptığı gibi topluma rehber olamadıklarını ve çeşitli konularda öncülük edemediğini belirten Seyda İlyas aslında genel olarak seydaların medresede okumamış din görevlilerine bakışını yansıtmaktadır. Diğer bir ifade ile geleneksel kurumların temsilcilerinin modern eğitime yönelttiği eleştiriler çoğunlukla daha önceki yerelgeleneksel din anlayışının izlerini taşımaktadır.

Imam hatip liselerinden mezun olanlar bizim toplumda yapamazlar zaten. Akaitleri fikıhlarl, insanların örf ve adetlerini bilmezler. Insanlarin sorunlarinı bilmezler 
dolayıslyla çare üretemezler, halka hitap edemezler. Simdi bir toplumun örf ve âdetini bileceksin ki çözüm üretebilesin. Onların dilinden konuşulması lazımdır ki, başkalarını barıştırabilsin (Yunus, 64 Yaşıında).

Benzer bir şekilde, resmi devlet okullarında eğitim gören kişilerin ilim ve önderlik yönünden eleştirildiği görülmektedir. Bu durum geleneğin aktörlerinin neden hala mevcut sistemlerini devam ettirmeye gayret ettiklerini ve kendilerini meşrulaştırma stratejilerini göstermektedir. Bununla beraber aynı seydaya geleneksel medrese eğitimini ve modern eğitimi karşılaştırmaları sorulduğunda;

Günün şartlarında daha araştırmacı bir kimliğe bürünmek için aslında ilahiyatı okumak lazım. Ilmi almak içinde medreseye gitmek lazım. Şimdi okuyan okumayan (ilahiyat) aradaki farklar barizdir. Yani elde etme imkânı azdır, okuyanların ise aletlerini almak için medreseye devam etmesi gerekir (Yunus, 64 Yaşında).

Soru sormayı gerektiren bu açıklamaya karşılık resmi din eğitimindeki öğrencilerin bilgi seviyesini nasıl değerlendiriyorsunuz? Sorusuna karşılık Seyda Halil;

Imam hatipte ilim yok, yani bu kitaplart ${ }^{4}$ onların önüne koyun bir kelime dahi okuyamaz. Arapça bilmiyor ki. Bu kitaplar harekesiz Arapça ile yazılmış. Yani şimdi siz bunu okuyamazsınız. Ama kişi medrese okumuşsa bunun ne olduğunu bilir. Fail meful nasıldır bilir. Yani geçmiş zaman kipi, emir kipi her kip var Arapçada. Bunlar için ilim gerekir (Halil, 33 Yaşında).

Benzer bir şekilde 'Sizce ilahiyat ve imam hatip liseleri öğrencilerinin eksik yönleri var mıdır varsa nelerdir?' Sorusuna karşılık Seyda İbrahim:

Bence devletin resmi kurumlarl halkın gerçek Íslamiyet'i ögrenmesini istemiyor. Öğrencileri çok gerekli olmayan şeylerin etrafinda dolandırtyorlar. Bence birazda mesleğin dışına çıkıyorlar. Yani en fazla olarak Kur'an ve hadisin öğrenilmesi, İslam fikhının ögrenilmesi gerekirken; fizik, kelam gibi ilahiyatçllara çok ait olmayan şeyler öğretiliyor. Yani bütün ilimler mutlaka faydalıdır, yani öğrenilmesi gereklidir, zararlı değildir. Fakat ağırlıklı olan dersler var. Bu derslerden Kur'an'ın hadislerin tam olarak öğrenilmesi, detayına kadar inilmesi gereklidir (İbrahim, 61 Yaşında).

Yukarıda görüldüğü üzere medresede eğitim veren Seyda Halil, bu kurumda öğretilen Arapça'yı kıstas alarak imam hatip öğrencilerinin kalitesini değerlendirebilmektedir. $\mathrm{Bu}$ durum medreselerin geleneksel boyutu ile ilgilidir. Osmanlı Devleti'ndeki medreselerde Arapça ilim dili olarak kullanılmış ve etkisinin halen devam ettiğini görmek mümkündür. Modern eğitimde Türkçe'nin temel eğitim dili olması doğal olarak Arapça'nın ikinci planda kalmasına neden olmaktadır. $\mathrm{Bu}$ nedenle geleneksel medreselerde Arapça'ya olan vurgu onların resmi eğitimi ve buradan mezun olan kişileri Arapça konusunda yetersiz görmelerine ve onlara karşı kendilerine bu noktada meşruiyet zemini inşa etmeye çalıştıkları görülmektedir. Ancak bu durum geleneksel medrese müdavimlerinin Arapça'yı önemli oranda önceleme riskini de doğurmaktadır. Çünkü normal şartlarda araç olan bu dilin amaç haline getirilmesi medreselerde öğrencilerinin dikkatlerinin dağıtmasına

4 Medreselerde okutulan, resmi eğitimden farklı ve tamamı Arapça olan müfredat kitapları neden olmaktadır. Saha çalışması sırasında birçok seyda tarafından dolaylı da olsa resmi eğitime benzer eleştirilerin getirildiği görülmüştür. Bunun altında yatan temel nedenini, İslam'ın tüm yönleri ile öğretilmesi yerine sadece modern ulus devletin izin verdiği ya da bazı durumlarda hükümetlerin dine yönelik politikaları ile genişleyen veya daralan bir içerikte görmek mümkündür. Türkiye'de din eğitiminin ve politikalarının devletin denetiminde ve gereksinimlerin doğrultusunda şekillendiğini aktaran Shively'e (2008: 684) göre, bu yöntemle bir taraftan İslam dini 'ehlileştirilmekte' diğer taraftan da dine artık devlete tehlike teşkil etmeyecek bir boyut kazandırılmaktadır. Benzer bir sonuca Yanmış'ın (2017: 243) da ulaştığı görülmektedir. Ona göre medrese çevresi, modern eğitimlerin, oraya katılan öğrencileri dinden çıkartacağına yönelik bir takım söylemler geliştirdiğini ve böylece bu eğitim sistemini ötekileştirmektedirler. Bu noktada aynı seydaya kendi öğrencilerini resmi eğitimdeki öğrenciler ile karşılaştırdıklarında hangi tür farklar gördükleri sorulduğunda;

Şimdi bana gelen ögrencilerin bir kısmı, imam hatip mezunuydu. İmam hatipten bize gelirken ben onlarl yüzdelik olarak yüzde onluk seviyesinde dahi görmedim, göremedim o kadar zayıftılar. Yani mesleki bilgi olarak slfirdılar. Fakat bunlar mezun olunca imamlık yaplyorlar. Onlar memurdur, memurlardan başka bir şey değildirler. Şimdi imam olabilmeleri için veya imamlıktan sonraki bir aşamaya ulaşabilmeleri için mutlaka bir Arapça ilmi bilmelidirler. Çünkü dinimizin ana kaynağı Arapça'dır. Kur'an'’, hadisleri çözebilmek için Arapça gereklidir. Ama imam hatipten mezun olanlar Arapça konusunda sıfirdırlar. Aynı şekilde ilahiyattan mezun olanlarda öyle (İbrahim, 61 Yaşında).

$\mathrm{Bu}$ doğrultuda aktörlerin resmi eğitim ile bütünleşmek isteyip istemedikleri sorulduğunda onların bu konuya isteksiz yaklaştıkları dikkat çekicidir. Çünkü resmi eğitimden uzak durmak isteyerek bu kurumu diğerleri ile entegre etmek istemedikleri anlaşılmaktadır.

Medreselerle ilahiyatların birleştirilmesi konusunda ümit var değilim. Tevhid-i Tedrisat Kanunu'nun amacı da buydu zaten. Çünkü ilahiyatların medreseleştirilmesi, medreselerin ilahiyatlaşması çok zor. Medreseleri özgün bir eğitim kurumu olarak ele almak gerekir (Süleyman, 55 Yaşında).

Medreselerin kendilerini ilahiyata alternatif bir kurum olarak gördüklerini yukarıdaki ifadelerden anlamak mümkündür. Bu nedenle Seyda Süleyman'ın ifade ettiği üzere Tevhid-i Tedrisat Kanunu'nun eğitim ve öğretimi birleştirme kapsamında yürürlüğe konulması onların birleşmesini ve kendilerini ayrı bir kurum olarak devam ettirmelerine neden oldu. Medreselerin seydalar tarafindan bu şekilde ayrı olarak konumlandırılması tarihsel bir kültüre dayanmalarının da etkisi oldukça büyüktür. $\mathrm{Bu}$ nedenle yeni oluşan bir kurum bünyesinde faaliyet göstermek onlar için bazı özelliklerinden ve yöntemlerinden taviz vermeyi gerektireceğinden onların bu tür birleşmeye sıcak bakmadıklarını anlamak mümkündür. Medreselerde yetişen din adamlarının devlet eliyle verilen din eğitimini tasvip etmemeleri doğal olarak onların alternatif yöntemler geliştirmelerine neden olmuştur. $\mathrm{Bu}$ geleneksel kurumun devam ettirilmesinde her ne kadar kültür ve iktidar ilişkileri önemli bir rol oynasa da, en azından Türkiye'nin Doğu ve 
Güneydoğu Anadolu bölgelerinde yerleşmiş bir kültür olarak din adamlarının medreseden mezun olmaları bu kurumu sahiplenen din adamlarının varlıklarını korumalarını ve resmi devlet kurumlarını eksik görmelerine neden olmaktadır. Örneğin bu konuda devletin din adamı yetiştirme müfredatını nasıl değerlendiriyorsunuz sorusuna karşılık Seyda Ebubekir:

Din adamı yetiştirme hususunda devletin müfredatı sıfirdır. Şimdi neler eksik diyorsunuz? Hali hazırda devletin o din adaminı yetiştirme hususunda kendi zihniyetine göre yerleştirmiş olduğu müfredat olduğu için sıfirdır diyorum. O müfredat ilmi olsa, bunlar edepten yoksun olurlar. Edepten yoksun olmasa bile tasavvuftan yoksundur. Bu üç kıstas olmadığından dolayı biz bunu eksik görüyoruz (Ebubekir, 38 Yaşıında).

Alan çalışması sırasında postnişin makamında bulunanlar ve köklü bir şeyhlik silsilesine dayanan seydaların tasavvufa yönelik çok fazla övücü sözler söylediği fark edilmektedir. Görüşme sırasında hemen hemen her firsatta ilim, edep ve tasavvuf üçlüsünün birlikteliğinden ve birinin eksik olması halinde kişin yetkin bir din adamı olamayacağını 1srarla belirten Seyda Ebubekir'in bu duruşu, aslinda medresede verilen ve bir dereceden sonra kutsallaştırılan kendi eğitimlerini farklı kılma gayreti içine girildiğini göstermektedir. Bununla beraber Seyda Ebubekir'in İlkokulu resmi devlet okulunda okuması ve yurtdışında medrese eğitimi alması onun bu tutumunu sergilemesinde önemli bir neden olduğunu ifade etmek mümkündür. Medreselerin içinde bulunduğu mevcut durum onların diğer gerek resmi gerekse gayri resmi eğitim kurumlarından ayırırken kullandıkları en önemli argüman daha öncede ifade edildiği üzere Arapça konusundaki bilgileridir. Arapçaya herhangi bir ilahiyat öğrencisinden çok daha fazla vakıf olan bu medrese öğrencilerinin daha sonra bunu maddi sermayeye dönüştürmekte oldukça mahir davrandıkları görülmektedir. Zaten yukarıda da görüldüğü üzere onlara medrese kurumunu ve ilahiyatları karşılaştırma ile ilgili herhangi bir soru yönelttiğinde referans noktaları Arapça olması bunu göstermektedir. Bu kapsamda Seyda Ahmet șunları aktarmaktadır:

Ben bunlarl söylediğim zaman bazen itirazlar çıkabiliyor. Bana, medreseleri çok abartıyorsun diyenler var. Biz kendi içimizdeyken bunları çok karıştırmam; çünkü burada zaten bir saldırl var. Sistematiği orada savunurum. Medreseden olmayan arkadaşlar bize şu sorununuz var. Bakın işte yazım tekniklerinde sıkıntı var. Bilgisayar kullanımda sıkıntı var. Ama bunlar aşılıyor. Şimdi ben medresedeki sıkıntıları okullardaki Arapça sikıntısıyla karşılaştırdığımda bizimkiler çok önemsiz kalıyorlar. Sempozyumlar düzenleniyor, YÖK'te toplantılar düzenleniyor, bu sorunu nasıl halledelim, nasıl sinıf koyalım ya da koymayalım gibi. Ama çözüm yok. Medreseye bir bilgisayar hocasını getir iki hafta üç haftada ögrencilerin hepsine bilgisayar kullanmasını ögretir. Ben medreseden çıktığım da kimse bana bilgisayarla ilgili bir yardımda bulunmad, öğretmedi. Çıktım kendim ögrendim Ama Arapça kendi kendine ögrenebilecek bir dil değil. Daha doğrusu ögrenciler talep etmiyor, böyle bir meraklart da yok (Ahmet, 30 Yaşında).

Zahiren bakıldığında gerçekten de medrese öğrencilerinin eksik kaldığı bilgiler en azından Türkiye şartlarında bir din adamından beklendiği dikkate alındığında daha kabul edilebilir olduğu görülmektedir. İslam dininin temel referans kaynaklarının Arapça olması ve Arapça dil yeteneğinin bu bilgilere hâkim olduğu hissini uyandırması doğal olarak medrese mezunlarının da ilahiyat mezunlarını dini bilgi yönünden yetersiz görmelerine neden olmaktadır. Fakat buna bağlı olarak kendi eksiklikleri olan özellikle teknolojik, akademik veri edinme ve kullanma becerilerinin oldukça basite indirgendiği anlaşılmaktadır. Buna rağmen yukarıda aktarıldığı üzere Türkiye'de medrese eğitim sistemi yasal zeminden mahrum olmakla beraber çıtılarının da kamusal alanda hiçbir karşılıkları mevcut değildir.

Saha çalışması sırasında görüşme yapılan dini aktörlerin birçoğu özellikle açık öğretim lisans ya da ön lisans programlarına kayıtlı iken bazılarının da yüksek lisans ve doktora programlarına kayıt yaptırdıkları fark edilmiştir. Bu durum onların geleneksel ancak yasal olmayan medrese eğitimlerinin resmi anlamada bir karşılığının olmamasından kaynaklandığı anlaşılmaktadır. Yukarıdaki görüşme notlarından da anlaşılacağı üzere gerek dini aktör olarak medresenin ana unsuru seydanın gerekse de okuttuğu öğrencilerinin bir taraftan medreseye devam ederken diğer taraftan da resmi eğitimin açık öğretim olarak sunmuş olduğu imkânlarından faydalanarak geçerli bir diploma almaya çalışmaları dikkat çekmektedir. Ancak görüşmelerden de anlaşılacağı üzere geleneksel din eğitiminin müdavimleri resmi eğitimi birçok noktadan eksik görmelerine rağmen kendi kurumlarından aldıkları belgelerinin devlet kurumlarında bir karşılığ1 olmadığg için resmi eğitim diplomaları almakta ve daha sonra bu diplomaları kullanarak çok büyük çoğunlukla devlet dairelerinde kamu görevlisi olarak çalışmaktadırlar. $\mathrm{Bu}$ noktada Türkiye'de 1924 yılında yasaklanan medrese eğitim sisteminin süreç içerisinde devam etmesinin de temel dinamiklerini ve referans noktalarını oluşturan din adamlarına-görevlilerine yönelik eleştirilerini şu şekilde sıralamak mümkündür:

1. Yerelin sorunlarından habersiz çoğunlukla teorik eğitim almaları

2. Yerel aktörlerin kendi meşruiyetlerini kaybetme endişesine bağlı olarak resmi din adamlarını ve aldıkları eğitimi eksik görmeleri

3. Resmi okullarda din eğitimi ile beraber temel kaynaklara ulaşma noktasında Arapçaya yönelik eğitimin eksikliği

4. İlmi yönden yetkin bir din görevlisi olamama

5. Toplumsal sorunların çözümüne öncülük veya aracilık edememe

6. Resmi din eğitiminde modern, laik, ulus devletin denetimi

Cumhuriyet felsefesinin en önemli aktarım organı olarak eğitim diğer alanlar gibi dini eğitiminde kendi denetiminde olması ile kurumsal olarak daha güçlü bir konum kazanır. Sistemin toplumdan talep ettiği bireyin yetişmesi ve içinde yetiştiği sistemin de önemli bir savunucusu olarak hareket etmesi deyim yerinde ise bu kişinin kültürlendiğinin bir göstergesi olarak karşımıza çıkar. Türk eğitim sisteminin üzerine temellendiği pozitivist-pragmatist felsefi düşünce sistemi açık bir şekilde bireyi sahada ortaya koyduğu işlev ile ele alıp değerlendirir (Şapolyo, 1966: 385-386). Bu yapının geleceğe aktarımı doğal olarak bu çalışmanın örneklem grubunu dışarıda bırakmış ve daha ulusal bir 
bireyi inşa etme misyonu ile şekillenmiştir. Çünkü geleneksel medreselerdeki din eğitimi bireyi öne çıkarmaktan ziyade talebenin benliğini köreltirken kişinin aldığ1 eğitimi ön plana çıkarmaya çalışmaktadır (Aşkın, 2018: 122). Bu noktada eğitimin sistem içerisinde dinden istifade ettiğini görmekle beraber onun belli bir yöne kanalize edilmesine de aracılık etmektedir (Şener, 2009:261). Bunun da ötesinde yeni kurulan ve kendisini seküler değerler ile tanımlayan devlet yönetiminde farklı eğitimlerin tek ve yine seküler bir zeminde toplanması (Shively, 2008: 684) bir anlamda buna uygun olmayan grupların yeni eğitim sistemine dâhil olmasını önlemiştir.

\section{Sonuç}

Osmanlı döneminde eğitimde meydana gelen ikililik, Cumhuriyet döneminde sona ermiş ve eğitimin hangi yönde olacağı tartışmasına, çıkarılan Tevhidi Tedrisat Kanunu ile son verilmiştir. Buna göre eğitim laik bir sistem üzere devam edecekti. Ancak Türkiye toplumunun gerek kültürel gerekse de tarihsel olarak İslam ile kurmuş olduğu ilişkinin özellikle Türkiye'nin Doğu ve Güneydoğu Anadolu bölgelerinde din eğitimi veren medreselerin devam etmesine neden olduğu görülmektedir. Özellikle son 10 yılda gerek molla alımı (2011 yılında) gerekse de medrese eğitiminin söz konusu bölgelerdeki halk üzerindeki etkileri Diyanet İşleri Başkanlığı'nca fark edilmesi yeni bir meşruiyet zeminin inşa edilme sürecini doğurmuştur. Müderris olarak medreselerde ders veren ancak halk arasında seyda olarak tabir edilen aktör eğitim kurumları olarak medreselerin sosyal ve siyasal olarak meşru kabul edilmeleri için modern eğitime ve ondan mezun olan din görevlilerine eleştiriler yöneltmektedirler.

Bunların başında resmi din eğitimi alarak mezun olan din görevlilerinin toplumu anlama ve yönlendirme konusu gelmektedir. Seydalara göre, sadece resm-teorik eğitim alarak din görevlisi olan bir kişi kendisini halka kabul ettirmekte zorluk çekebilirken onları anlamaktan da uzak kalmaktadır. $\mathrm{Bu}$ din görevlileri topluma rehberlik ve öncülük etmede, kendisine intikal eden sorunlara çözüm bulmada, gelenek ve görenekleri anlamlandırmada yetersiz kaldıkları düşünülerek seydalar tarafindan eleştirilmektedirler. Görevli bazında yapılan eleştirilere ek olarak seydalar, resmi eğitimin içeriğine de çeşitli eleştirilerek getirerek medreselerdeki özellikle Arapça eğitimi öne çıkarılmaktadır. Arapça'nın dilbilgisi yapısı ve medrese kitaplarının Arapça olması deyim yerinde ise seydaların elini güçlendirmekte ve resmi eğitim bu minvalde sıkı bir eleştiriye tabi tutulmaktadır. Bu noktada seydalar resmi eğitimdeki Arapça dil eğitimi ve mezunlardaki Arapça dil bilgisi eksikliği her firsatta dile getirilmekte ve bunun dini terminolojiye hâkim olmak için taşıdığı önem öne çıkarılmaktadır. Devletin din eğitimindeki denetim ve din görevlilerinin tabi olduğu sistem yine seydalar tarafından eleştirilen konular arasında yer almaktadır.

Yukardaki görüşmelerden anlaşılacağı üzere medrese müderrisleri olarak seydaların eleştirileri belli noktalarda yoğunlaşmaktadır. Bunların ise çoğunlukla onların kendi medreselerinin devam etmesine bir dayanak olarak sunulmaktadır. Bir taraftan laik-ulus devletin din eğitimi üzerindeki denetimi diğer taraftan resmi din eğitiminin kendi içindeki eksiklikleri ile ilgili düşünceleri onların eleştirilerine kapı aralamaktadır. Böylece eleştiriler Arapça eğitimi, yetersiz ve kalitesiz müfredat, eğiticilerin yetersizliği ve en önemlisi de onların kültürel ve tarihsel olarak toplumda kazanmış oldukları toplumsal kabul ve prestijlerine sahip olmamaları seydaların tekrardan geleneksel medrese eğitimini öne çıkarmaya yönelik çalışmalarına yön ve bir anlamda da onlara moral verdiği görülmektedir.

\section{Kaynakça}

Akşit, B. Ve Coşkun, M. K. (2004) Türkiye'nin Modernleşmesi Bağlamında İmam Hatip Okulları Modern Türkiye'de Siyasi Düşünce: İslamcllk İçinde, (Ed. Y. Aktay). İstanbul: İletişim Yayınları.

Aşkın, D. (2018). Din, Gelenek ve Modernleşme: Türkiye'de Şark Medreseleri ve Seydalar. Ankara: Nobel Yayınları.

Aşkın, D., Suğur, N . (2019). Geleneksel Otorite ve Liderlik: Dini Aktörler Olarak Seydalarda Dinsel İtibarın İnşa Süreçleri. MUKADDİME, 10 (1), 195 212. DOI: $10.19059 /$ mukaddime.460718

Bayar, Y. (2012). The Dynamic Nature Of Educational Policies And Turkish Nation Building: Where Does Religion Fit İn? Secular State And Religious Society: Two Forces In Play In Turkey İçinde. (Ed: B. Turam). New York: Palgrave Macmillan. Ss. 19-38.

Bodur, H. E. (2007). Küreselleşme, Din Ve Ulus-Devlet. Küreselleşme Ulus-Devlet Ve Din İçinde, (Ed: Ş. Gürsoy Ve İ. Çapcioğlu). Ankara: Platin Yayınları. Ss.17-42.

Büyüköztürk, Ş. Vd. (2012). Bilimsel Araştırma Yöntemleri (11. Bask1). Ankara: Pegem Akademi.

Çağlayan, E. (2018). Kemalist Ulus Devletin İnşası. Istanbul: Açılım Kitap.

Çiçek, H. (2009). Şark Medreselerinin Serencamı. İstanbul: Beyan Yayınları.

Durkheim, E. (1977). On Education And Society. Powder And Ideology In Education. (Ed. J. Karabel Ve A.H. Halsey), 92-105. New York: Oxford University Press.

Gül, A. (1997). Osmanlı Medreselerinde Ĕ̆itim-Öğretim Ve Bunlar Arasında Daru'l Hadislerin Yeri. Ankara: Türk Tarih Kurumu Basımevi.

Maltaş, R. (2011). Sümerlerden Günümüze Eğitim: İlk Ve Ortaçă̆. Konya: Çizgi Kitabevi.

MEB (Milli Eğitim Bakanlığı). (2017). Milli Eğitim İstatistikleri Örgün Eğitim 2016/2017 (National Education Statistic Formal Education 2016/2017). Http://Sgb.Meb.Gov.Tr/Www/İcerik_Goruntule.Php ?Kno=270

Neuman, W.L. (2012). Toplumsal Araştırma Yöntemleri: Ntiel Ve Nicel Yaklaşımlar (1.Cilt). (5. Baskı). (Çev: S. Özge). Ankara: Yayın Odası.

Öcal, M. (2008). Türkiye'de Din Eğitimi Tarihi Literatürü, Türkiye Araştırmaları Literatür Dergisi, 6 (2), 399430. 
Rıfkı, F. (1933). Bizim Köy. Kadro. (Cilt: 2) (Kadro-1933, Cilt:2, Tipkibasım, Yay. Haz. C. Alper. Ankara: Ankara İktisadi Ve Ticari İlimler Akademisi Yayın No: 130, 1979), (18). 15-17.

Russel, B. (2002).Ĕ̌itim Üzerine. (Çev.N. Bezel). İstanbul: Say Yayınları.

Shively, K. (2008). Taming Islam: Studying Religion in Secular Turkey. Anthropological Quarterly 81(3):683-71.

SDAM (Strateji Düşünce Ve Analiz Merkezi). (2016). Türkiye'de Medreseler Ve Din Eğitimi. Http://Www.Stratejidusunce.Org/Detay/Haber/1005/ Turkiyede-Medreseler-Ve-Din-Egitimi.Aspx

Şapolyo, E. B. (1966). Atatürk Ve Maarif Misak1Pragmatizm-. Türk Kültürü. (40). 383-394.

Şimşek, E. (2013).Çok Partili Dönemde Yeniden Din Eğitimi Ve Öğretimine Dönüş Süreci (1946-1960). A. Ü. Türkiyat Araştırmaları Enstitüsü Dergisi. (49). 391-414.

Talas, M. A. (2000). Nizamiye Medreseleri Ve Íslam'da Eğitim-Öğretim (S. Cihan, Çev.). Samsun: Etüt Yayınları.
Türk, E. (1999). Milli Eğitim Bakanlığında Yapısal Değişmeler: Türk Eğitim Sistemi. Ankara: Nobel Yayın Dağıtım.

Vahide, Ș. (2006). Bediuzzaman Said Nursi’s Approach To Religious Renewal And its Impact On Aspects Of Contemporary Turkish Society, The Blackwell Companion To Contemporary Islamic Thought. İçinde (Ed: İ. M. Abu-Rabi). Malden: Blackwell Publishing. Ss.55-74.

Weber, M. (2012). Ekonomi Ve Toplum. Cilt: 1. (Çev. L. Boyac1). İstanbul: Yarın Yayınları.

Yalar, M. (2012).Seyda, Mela Ve Feqilerin Bölgenin Dini Kültürel Hayatındaki Yeri. Medrese Geleneği Ve Modernleşme Sürecinde Medreseler Sempozyumu (Yayına Hazırlayan: F. Gedikli). Muş: Muş Alparslan Üniversitesi, Cilt: 1, Ss.459-470.

Yanmış, M. (2017). Yakın Dönemde Kürtler: Kimlik, Din, Gelenek. İstanbul: Grifon Kitap.

Yavuz, H. (1999). The Assassination Of Collective Memory: The Case Of Turkey, The Muslim World. 89 (3-4). Ss. 193-207. 